\title{
Скринінг сонних артерій у хворих на цүкровий діабет: методологія і клінічна значимість
}

\section{М.С. Черська,}

\section{Х.М. Кухарчук,} О.А. Гайова

ДУ «Інститут ендокринології та обміну речовин ім. В.П. Комісаренка НАМН України»

\begin{abstract}
Резюме. Цукровий діабет (ЦД) є незалежним фактором ризику розвитку фатальних і нефатальних серцевосудинних захворювань (СС3). На сьогодні, за даними Всесвітньої організації охорони здоров'я, у світі на ЦД хворіє близько 422 млн людей, що становить 8,8\% усього населення планети. Встановлено, що СС3 є основною причиною смерті у хворих на ЦД. Також тривожить те, що за ЦД досить часто спостерігається ураження судин. Причиною цьому є патогенетично обгрунтоване швидке прогресування атеросклеротичного ураження судин, яке може безсимптомно прогресувати десятки років до моменту настання несприятливих серцево-судинних подій. Варто враховувати, що на фоні ЦД зміни судинної стінки у вигляді атеросклеротичного ураження мають більш прогресуючий перебіг, ніж у пацієнтів без ЦД. Все це вказує на потребу ранньої діагностики змін судинної стінки у хворих на ЦД. Підтвердженням цьому є результати низки клінічних досліджень, в яких рекомендовано розцінювати ультразвукову діагностику (УзД) судин, а саме сонних артерій, як скринінговий метод «першої лінії атеросклеротичного ураження, особливо у хворих на ЦД. Цей метод є не лише неінвазивним, безпечним, безболісним, швидким та не дорогим, але й достовірним. УзД судин дає можливість на ранніх етапах виявляти початкові і вже наявні атеросклеротичні зміни судинної стінки в безсимптомних хворих, контролювати ефективність лікування та подальше прогресування захворювання. У статті представлено методологію визначення і клінічну значимість ранніх маркерів атеросклерозу — товщина комплексу інтима-медіа та наявність атеросклеротичних бляшок - за допомогою УЗД судин. Використання УЗД сонних артерій, як метода вибору у хворих на ЦД, дозволить своєчасно виявляти ризик розвитку ССЗ та їх ускладнень у пацієнтів на ЦД.
\end{abstract}

Ключові слова: цукровий діабет, серцево-судинні захворювання, ультразвукова діагностика судин шиї, товщина комплексу інтима-медіа, атеросклеротична бляшка.

ЦД - це хронічне та прогресуюче захворювання, яке є однією з головних та незалежних причин розвитку ССЗ. Доведено, що ризик розвитку СС3 у чоловіків, хворих на

* Адреса для листування (Correspondence): ДУ «Інститут ендокринології та обміну речовин ім. В.П. Комісаренка НАМН України», вул. Вишгородська, 69, м. Київ, 04114, Україна. E-mail: emariya83@gmail.com
ЦД, у 2-3 раза, а в жінок - у 3-4 раза вищий, ніж в осіб без ЦД [1]. Поширеність ішемічної хвороби серця (IXC) серед хворих на ЦД у 2-4 раза вища, ніж у хворих без ЦД, ризик розвитку інфаркту міокарда - у 6-10 разів та інсульту - у 4-7 разів [2]. 
Лекції

За даними Всесвітньої організації охорони здоров’я на сьогодні у світі на ЦД хворіє близько 422 млн людей, що становить 8,8\% усього населення планети. За прогнозом Міжнародної федерації діабету (International Diabetes Federation, IDF) до 2040 року кількість хворих на ЦД збільшиться до 642 млн та буде становити 10,4\% усього населення планети [1, 3].

Однією з основних причин раннього розвитку ССЗ та їх ускладнень у хворих на ЦД є прискорений розвиток атеросклерозу. Патогенез діабетичного атеросклерозу доволі складний. Відомо, що вплив гіперглікемії на процеси атерогенезу реалізується шляхом розвитку генералізованої дисфункції ендотелію, оксидантного стресу і збільшення концентрації кінцевих глікозильованих продуктів обміну $[2,4]$.

Внаслідок наявної у хворих на ЦД гіперглікемії збільшується продукція активних форм кисню, що призводить до накопичення супероксид-радикалів у мітохондріях та пошкодження судинної стінки. Також прогресуванню атеросклерозу сприяє надмірне утворення внутрішньоклітинних кінцевих продуктів глікування, активація протеїнкінази С, гексозаміновий шлях метаболізму глюкози, що може посилювати продукцію активних форм кисню. Останні, зі свого боку, активують прозапальні шляхи, що пов'язані з ключовими молекулярними процесами атерогенезу [4].

Варто відмітити, що на фоні гіперглікеміі збільшується також кількість потенційно-патогенних грамнегативних бактерій у кишківнику, які виділяють близько 90\% усіх ендотоксинів. За високої концентрації останніх модифіковані ліпопротеїди низької щільності чинять цитотоксичну та пошкоджуючу дію на ендотеліальні клітини, тим самим впливають на фіксацію до них макрофагів, стимулюють ріст гладком'язових клітин і пригнічують рух макрофагів у субендотеліальному просторі. Таким чином, регенеровані після пошкодження ендотеліальні клітини здатні захоплювати 3 плазми крові підвищену кількість ліпопротеїдів низької щільності [5].

Оксидантний стрес та запалення знижують активність $\beta$-клітин підшлункової залози і їх чутливість до інсуліну. Все це утворює замкнуте коло, яке сприяє формуванню діабетасоційованого атеросклерозу [4].
Враховуючи вище викладене, ми вирішили проаналізувати опубліковані наукові дані щодо значущості використання УЗД судин у хворих на Цд для ранньої діагностики атеросклеротичного ураження судин та визначення ризику розвитку ССЗ.

На сьогодні УЗД набуває все більш широкого використання, оскільки цей метод є неінвазивним, безболісним, безпечним і недорогим. Для діагностики атеросклеротичного ураження судин перевагу надають огляду загальних сонних артерій (ЗСА), оскільки вони найбільш доступні для дослідження і дозволяють робити висновок про поширеність і вираженість атеросклеротичного процесу в інших судинних басейнах [6].

Для оцінки атеросклеротичних змін судинної стінки рекомендовано спочатку вимірювати товщину комплексу інтима-медіа (ТКІМ). У своєму дослідженні P. Pignoli одним із перших за допомогою УЗД судин на рівні ЗСА виміряв ТКІМ та порівняв отримані значення 3 даними патологоанатомічного дослідження $[7,8]$. Оскільки показники не відрізнялись один від одного, це дозволяє розцінювати отримані за допомогою УЗД значення як достовірні.

Низка клінічних досліджень, проведених серед осіб молодого віку з низьким (<5\%) ризиком розвитку СС3 по шкалі Framingham Risk Score (FRS) за допомогою УЗД сонних артерій, продемонстрували наявність початкових атеросклеротичних змін судинної стінки [8].

Дослідницька група PROG-IMT провела всебічний мета-аналіз 3902 хворих на ЦД 2-го типу, зібраних шляхом об'єднання в популяційну когорту [9]. Вони дійшли висновку, що коефіцієнт небезпеки (КН) СС3 становить 1,22 при визначенні середнього значення ТКІМ і 1,23 при визначенні максимального значення ТКІМ після коригування традиційних факторів ризику. Значної різниці між цими двома методами визначення ТКІМ не встановлено, але коефіцієнт небезпеки у хворих на ЦД був вищим, ніж в осіб без ЦД і він становив 1,22 і 1,15 відповідно. Отже, асоціація між ТКІМ та ССЗ є більш очевидною у хворих на Цд.

Аналіз п'яти проспективних досліджень, що включали 3263 хворих на ЦД без СС3, 
показав, що середній показник ТКІМ (КН становив 1,08 за кожний приріст ТКІМ на 0,1 мм), максимальний показник ТКІМ (КН становив 1,07 за кожний приріст ТКІМ на 0,1 мм) і максимальне значення ТКІМ у сегментах ЗСА, на рівні біфуркації 3СА та у внутрішній сонній артерії (BCA) (КН становив 1,08 за кожний приріст на 0,1 мм) на етапах ранньої діагностики можуть бути провісниками розвитку СС3 (зокрема, ураження коронарних артерій, порушення мозкового кровообігу або захворювання периферичних артерій) у безсимптомних хворих на ЦД 2-го типу, навіть після корекції традиційних факторів ризику $[11,12]$.

Таким чином, визначення ТКІМ є обов'язковим у хворих на ЦД для раннього виявлення атеросклеротичних змін судинної стінки та ризику розвитку ССЗ, особливо у хворих без клінічних проявів атеросклерозу.

Для отримання достовірних даних слід чітко дотримуватись методики проведення УЗД судинної стінки. ТКІМ вимірюють по задній стінці 3СА, оскільки таке визначення відображає справжню біологічну товщину задньої стінки. Вимірювання ТКІМ по передній стінці ЗСА має вищий ризик припуститися помилок, оскільки ехогенність зовнішнього шару - адвентиції, може вплинути на візуалізацію межі медіа-адвентиція. Проте ТКІМ слід вимірювати також і по передній стінці ЗСА, оскільки атеросклеротичні зміни мають властивість розвиватися і в ній [11].

Японська академія нейросонології рекомендує вимірювати ТКІМ у трьох ділянках 3СА, у ділянці біфуркації 3СА та у внутрішній сонній артерії з наступним визначенням серед них максимального значення ТКІМ. Розрахунок середнього значення ТКІМ проводять за формулою $(\mathrm{a}+\mathrm{b}+\mathrm{c}) / 3$ шляхом визначення найбільшої величини ТКІМ ЗСА (a), потім на 1 см дистальніше (b) і на 1 см проксимальніше (c) від найбільшої величини ТКІМ (рис. 1). У клінічних дослідженнях для визначення ТКІМ рекомендовано користуватись автоматичним вимірюванням у кількох точках задньої стінки ЗСА дистальніше на 1 см або 2 см $[10,13,14]$. В якості норми для ТКІМ рекомендований показник $<0,9$ мм [14].

Обстеження 390 хворих із церебральним атеросклерозом (ЦА) на фоні ЦД дозволило встановити, що 73,4\% хворих із ЦА та

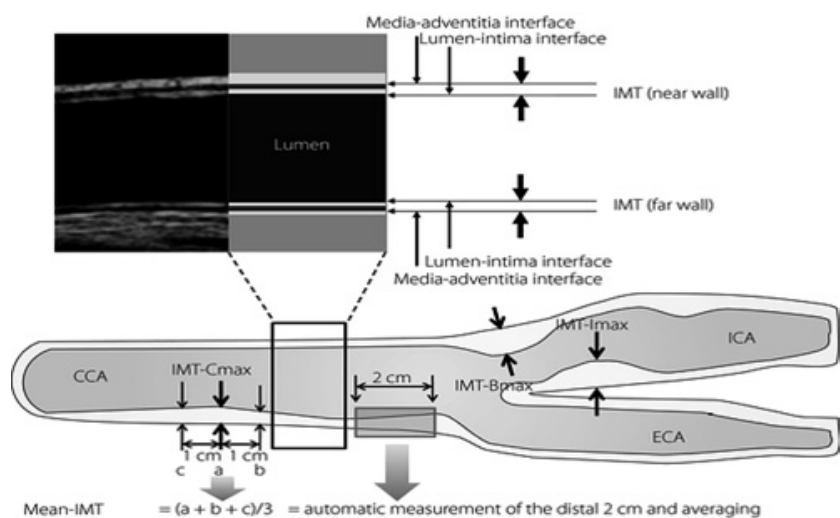

Рис. 1. Визначення комплексу інтима-медіа та розрахунок товщини комплексу інтима-медіа [11].

Fig. 1. Determination of the intima-media complex and calculation of the thickness of the intima-media complex [11]

ішемічним інсультом в анамнезі мали рівномірне підвищення ехогенності та потовщення КІМ ЗСА більше 1,0 см з обох сторін із частковою втратою диференціювання стінки судини на шари порівняно з 7,4\% хворих, які мали початкові прояви ЦА [15].

Під час обстеження 332 амбулаторних хворих на ЦД 2-го типу, в анамнезі яких відсутні стенокардія, інфаркт міокарда і втручання на коронарних артеріях, було проведено мультиспіральну комп'ютерну томографію, коронарну ангіографію та УЗД ЗГА з метою вивчення маркерів каротидних атеросклеротичних бляшок - сумарної та максимальної товщини бляшки, у поєднанні з показниками ТКІМ для виявлення обструктивної ішемічної хвороби серця у безсимптомних хворих на ЦД 2-го типу [9].

У результаті, серед 119 обстежених зі сумарною товщиною бляшки $<2,6$ мм, лише $25,2 \%$ осіб мали обструктивну IXC; за сумарної товщини бляшки $<2,6$ мм та ТКІМ $<0,725$ мм жоден з обстежених не мав ознак обструктивної IXC [9]. Серед 213 обстежених зі сумарною товщиною бляшки $\geq 2,6$ мм 79,8\% осіб мали обструктивну IXC; за TКIM $\geq 0,675$ мм на фоні гіперглікемії 84\% осіб мали обструктивну IXC. Серед 159 обстежених за максимальної товщини бляшки $<2,1$ мм у $44 \%$ осіб було виявлено обструкційну IXC; серед 173 обстежених за максимальної товщини бляшки $>2,1$ мм, $85 \%$ осіб мали обструкційну IXC.

Отже, визначення за допомогою УЗД маркерів каротидних атеросклеротичних бляшок разом із ТКІМ є найбільш точним скринінговим 
Лекції

тестом «першої лінії» для виявлення ранніх предикторів атеросклерозу у хворих на ЦД.

Під час обстеження 1065 хворих на Цд і безсимптомним ураженням сонних артерій атеросклеротичними бляшками з наступним визначенням рівнів стенозу встановлено, що лише $20 \%$ осіб із ЦД і безсимптомним стенозом сонних артерій $\geq 50 \%$ мають шанс вижити в наступні 12 років [16]. Крім того, у хворих на ЦД і рівнем стенозу $<50 \%$ ризик смерті від ССЗ порівняно 3 хворими, які не мали ЦД, збільшується майже у 2,5 раза. Також було встановлено, що стеноз сонних артерій у хворих на ЦД покращував стратифікацію ризику на 40\% для визначення ризику загальнопричинної та серцево-судинної смертності. У хворих на ЦД із безсимптомним атеросклерозом сонних артерій рівні HbA1c та глюкози в сироватці крові продемонстрували слабку асоціацію із серцево-судинною смертністю (на відміну від рівня стенозу сонних артерій) після 12-ти років спостереження.

Дослідження REACH (The reduction of Atherothrombosis for Continued Heath) продемонструвало, що внаслідок ураження атеросклерозом судин одного басейну серцевосудинні події розвиваються в 34,1\% випадків, двох басейнів - у 40,8\% випадків, трьох басейнів - 83,5\% випадків [17]. Отже, наявність атеросклеротичних бляшок та рівень стенозу сонних артерій, особливо у хворих на ЦД, має розцінюватись як свідчення наявних безсимптомних ознак ССЗ.

Зазвичай, атеросклеротичні бляшки виникають у ділянці низького гемодинамічного удару та неламінарного турбулентного кровотоку, наприклад у цибулині ЗСА та в проксимальних відділах внутрішньої сонної артерії, рідше в дистальних відділах 3СА. Варто зазначити, що ліва сонна артерія частіше зазнає атеросклеротичного ураження. Показано, що артеріальна стінка лівої сонної артерії товстіша ніж правої, як в осіб похилого віку, так і в осіб 3 атеросклеротичним ураженням [18]. Така асиметрія може бути пов'язана з анатомічними особливостями, адже права сонна артерія відходить від плечового стовбура, а ліва - від дуги аорти і є довшою на 20-25 мм. Відомо, що чим довша і звивистіша судина, тим більша вірогідність порушення гемодинаміки, особливо за наявності «проатеросклеротичних» умов, як то у хворих на ЦД.
У багатоцентровому перехресному дослідженні CARE - II взяло участь 584 хворих із наявною церебральною ішемією, серед яких 182 особи мали ЦД [19]. У результаті однофакторного аналізу було показано, що у хворих на ЦД із наявною церебральною ішемією на відміну від хворих без ЦД середня товщина судинної стінки становила 33,7 мм проти 31,1 мм; максимальна ТКІМ - 3,2 мм проти 2,8 мм; наявність кальцифікації - 51,6\% проти $36,6 \%$; багате на ліпіди некротичне ядро 77,5\% проти 58,5\%. Було зроблено висновок, що у хворих на ЦД частіше реєструють бляшки з кальцифікаціїєю і багатим на ліпіди некротичним ядром, що є фактором високого ризику розвитку тяжких судинних захворювань, особливо інсульту.

Атеросклеротичною бляшкою вважають локальну структуру, яка виступає в просвіт артерії не менше ніж на 0,5 мм, або збільшення ТКІМ на 50\% порівняно з відповідним показником в навколишньому оточенні, або TКІМ>1,5 мм [20].

Відомо, що гіпоехогенні бляшки передбачають майбутні інсульти, а гетерогенні бляшки зі складною ехо-моделлю більш схильні до розриву, ніж гомогенні.

Саме тому, під час опису атеросклеротичної бляшки варто охарактеризувати її ехогенність, однорідність та стан поверхні (рис. 2). По ехогенності розрізняють гіпоехогенні, ізоехогенні та гіперехогенні атеросклеротичні бляшки; по однорідності - гетерогенні (неоднорідні) або гомогенні (однорідні) бляшки. Вважають, що атерома і гематома представлені гіпоехогенними ураженнями, фіброз - ізоехогенними ураженнями, а кальцифікація - гіперехогенними ураженнями [21].

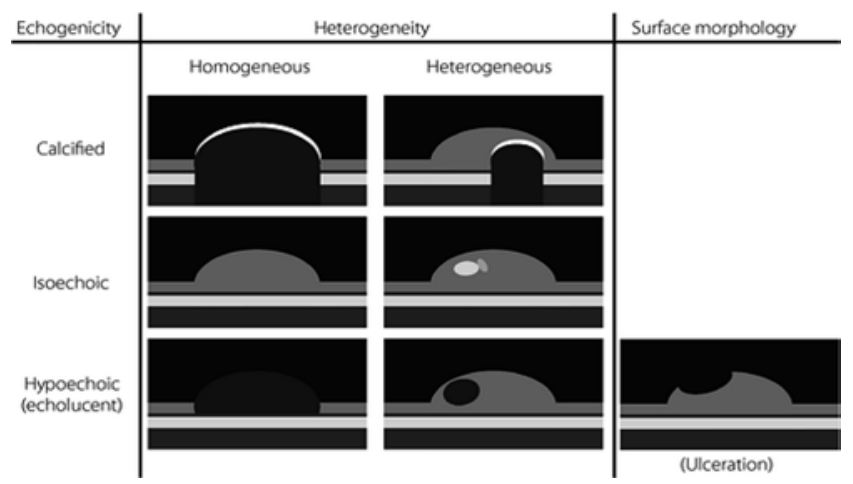

Рис. 2. Характеристики атеросклеротичних бляшок [11].

Fig. 2. Characteristics of atherosclerotic plaques [11]. 
Виділяють шість типів бляшок [21] (рис. 2):

1. Однорідні атеросклеротичні бляшки (ізоехогенні, анехогенні та гіперехогенні) 1, 2 та 3 тип.

2. Неоднорідні атеросклеротичні бляшки:

а) із переважанням гіпоехогенних зон у бляшці без порушення цілісності поверхні - 4-й тип;

b) із переважанням гіпоехогенної зони в бляшці з порушенням цілісності поверхні - 5-й тип;

c) на фоні чергування ан- і гіпоехогенної зон із переважанням компонентів високої ехогенності і з наявністю чи відсутністю акустичної тіні - 6-й тип.

Морфологію поверхні бляшки класифікують як гладку, нерівну і виразкову, а більш високий ризик виникнення інсульту пов'язують із виразковими (дефект $>2$ мм) або нерівними (дефект <2 мм) бляшками. Однак оцінка морфології тканин за допомогою вищезазначеного підходу є суб'єктивною та якісною $[11,13]$.

За локалізацією щодо поперечного перерізу атеросклеротичні бляшки описують як такі, що займають одну стінку судини; напівконцентричні - дві стінки судини; концентричні - більше двох стінок судини - (рис. 3). За локалізацією щодо поздовжнього перерізу описують локальні бляшки довжиною $<15$ мм) і пролонговані довжиною $\geq 15$ мм [13].

Планіметричне вимірювання ступеня стенозу атеросклеротичної бляшки ЗСА можна розрахувати за допомогою вимірювання площі або діаметра судини при поперечному скануванні. Однак слід враховувати, що результат розрахунку за площею буде на 10-20\% більше,

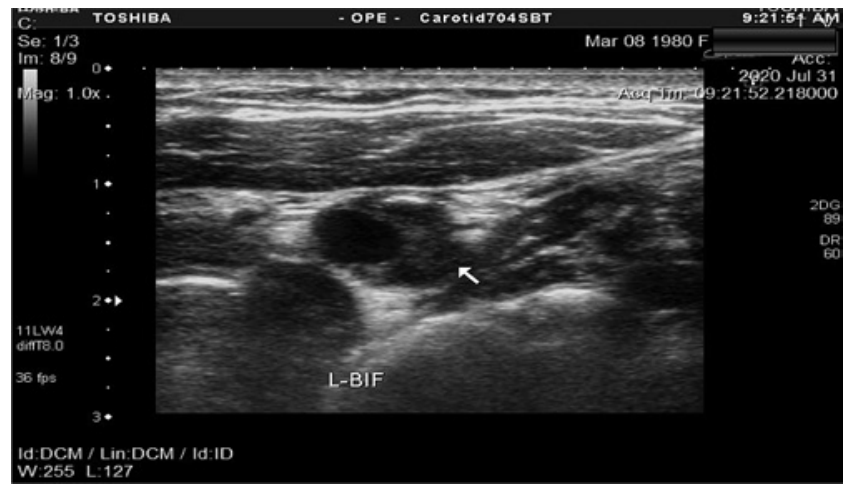

Рис. 3. Концентричне розташування атеросклеротичної бляшки у внутрішній сонній артерії (BCA).

Fig. 3. Concentric location of atherosclerotic plaque internal carotid artery. порівняно з розрахунком за діаметром. Тому, під час визначення рівня стенозу перевагу слід надавати розрахунку за діаметром [22].

Планіметричне вимірювання рівня стенозу у ВСА можна здійснити двома основними методами: європейським (European Carotid Surgery Trial - ECST) та північноамериканським (North American Symptomatic Carotid Endarterectomy Trial - NASCET). Метод ECST описує рівень стенозу безпосередньо в місці атеросклеротичної бляшки, метод NASCET оцінює ступінь звуження просвіту артерії відносно дистальної ділянки ВСА. Показники стенозу цих двох методів різняться один від одного: 70\%-ий стеноз за методом ECST відповідає 50\%-му стенозу за методом NASCET [22]. Розрахунок рівнів стенозів представлено на рис. 4 [23].

У протоколі дослідження слід вказувати рівень стенозу, розрахований двома методами. Слід зазначити, що ступінь стенозу менше 50\% за методом ECST може мати від'ємне значення під час розрахунку за методом NASCET. Виходячи з цього можна зауважити, що під час отримання ступеня стенозу менше 50\% за методом ECST подальші розрахунки за методом NASCET недоцільні [22].

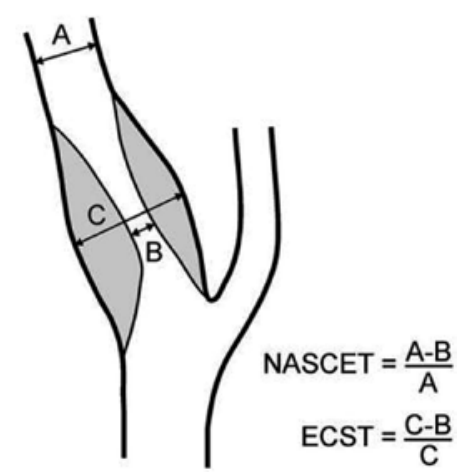

Рис. 4. Схема методики вимірювання стенозу артерії методами NASCET і ECST.

Fig. 4. Scheme of methods for measuring arterial stenosis by methods NASCET and ECST.

Примітка:

A-істинний діаметр BCA (NASCET);

$B$ - діаметр залишкового просвіту в стенозі (ділянка

максимального звуження);

C-істинний діаметр BCA (ECST);

Note:

A - true diameter internal carotid artery (NASCET);

$B$ - diameter of the residual lumen in the stenosis (area of maximum narrowing);

C - true diameter internal carotid artery (ECST). 
Лекції

Під час спостереження в динаміці прогресування стенозу фіксують у випадку, якщо приріст показників становить не менше 1/10 відносно попередніх. Наприклад, якщо стеноз BCA в 40\% при визначенні через рік становить $43 \%$, то це розцінюється як стеноз «без динаміки», але якщо стеноз становить 45\%, то це розцінюється як «прогресування ступеня стенозу в динаміці» [22].

Ступінь стенозу ВСА можна визначити також за допомогою аналізу спектра доплерівського зсуву частот [21]:

- стеноз <40\% - спектр доплерівського зсуву частот не виявляє відхилення від норми;

- стеноз 40-59\% - форма контуру спектра доплерівського зсуву частот не змінюється; відмічають спектральне розширення доплерівського зсуву частот 3 одночасним зменшенням або зникненням вікна під систолічним піком;

- стеноз 60-74\% - збільшується систолічна швидкість кровотоку, змінюється форма контуру спектра; спостерігається значне розширення спектра з заповненням вікна під систолічним піком; реєструється негативне значення доплерівського зсуву частот;

- стеноз 75-90\% - наявні всі ознаки, характерні для ступеня стенозу 60-74\%; окрім цього, реєструється негативне значення доплерівського зсуву частот;

- стеноз $>90 \%$ - на рівні стеноза спостерігається значне зниження швидкості кровотоку і різка деформація форми спектра безпосередньо за бляшкою з усіма ультразвуковими ознаками, характерними для стенозу 75-90\%.

Для визначення стенозу ВСА використовують також доплерографічні критерії в місці максимального стенозу судини, які наведені в табл. [22].

Варто враховувати, що точність доплерографічних показників стенозу гірша, ніж планіметричних [20].

Таким чином, ЦД є вагомим фактором ризику виникнення та прогресування ССЗ. Доказом цього є низка клінічних досліджень, проведених у різних популяціях. Важливим $є$ опосередкована оцінка стану судин усіх органів та систем на ранніх етапах захворювання за допомогою методу УЗД сонних артерій, як неінвазивного, безпечного, безболісного, швидкого і достовірного методу.

\section{Висновок}

УЗД сонних артерій дозволяє на ранніх етапах виявити як початкові зміни судинної стінки, так і загрозливі для життя стани, і визначити подальшу тактику ведення хворого на Цд без клінічних ознак розвитку і прогресування СС3. Визначення каротидних атеросклеротичних бляшок разом із ТКІМ є найбільш точним скринінговим тестом «першої лінії» для виявлення ранніх предикторів атеросклерозу у хворих на ЦД. Для отримання найбільш точного результату дослідження необхідно чітко дотримуватись методики проведення УЗД, акцентувати увагу на наявних змінах судинної стінки, рівні стенозів, структурних характеристиках атеросклеротичних бляшок, стану

таблиця. Дуплексні критерії ступеня стенозу BCA (по Grant E.G. et al., 2003), [22].

Table. Duplex criteria for the degree of internal carotid artery stenosis (according to Grant E.G. et al., 2003) [22].

\begin{tabular}{|c|c|c|c|c|}
\hline \multirow[t]{2}{*}{$\begin{array}{l}\text { Стеноз, \% } \\
\text { Stenosis, \% }\end{array}$} & \multicolumn{2}{|l|}{$\begin{array}{l}\text { Первинні параметри } \\
\text { Primary parameters }\end{array}$} & \multicolumn{2}{|l|}{$\begin{array}{l}\text { Додаткові параметри } \\
\text { Additional parameters }\end{array}$} \\
\hline & $\begin{array}{l}\text { Vps } \mathrm{BCA}, \mathrm{cm} / \mathrm{c} \\
\text { Vps internal carotid } \\
\text { artery, cm/s }\end{array}$ & $\begin{array}{l}\text { Ультразвукова оцінка } \\
\text { бляшки } \\
\text { Ultrasound assessment of } \\
\text { plaque }\end{array}$ & $\begin{array}{l}\text { Vps BCA / Vps 3CA, y.o. } \\
\text { Vps internal carotid artery / } \\
\text { Vps common carotid artery, } \\
\text { c. u. }\end{array}$ & $\begin{array}{l}\text { Ved } \mathrm{BCA}, \mathrm{cm} / \mathrm{c} \\
\text { Ved internal carotid } \\
\text { artery, } \mathrm{cm} / \mathrm{s}\end{array}$ \\
\hline $\begin{array}{l}\text { Hopma } \\
\text { Norm }\end{array}$ & $<125$ & $\begin{array}{l}\text { Heмaє } \\
\text { None }\end{array}$ & $<2,0$ & $<40$ \\
\hline$<50$ & $<125$ & $<50$ & $<2,0$ & $<40$ \\
\hline $50-69$ & $125-230$ & $\geq 50$ & $2,0-4,0$ & $40-100$ \\
\hline$\geq 70$ & $>30$ & $\geq 50$ & $>4,0$ & $>100$ \\
\hline
\end{tabular}

Примітка: Vps - пікова систолічна швидкість кровотоку; Ved — кінцево-діастолічна швидкість кровотоку.

Note: Vps — peak systolic blood flow velocity; Ved — end diastolic blood flow velocity. 
поверхні, оскільки ці характеристики можуть спонукати до негайних дій щодо подальшого дообстеження чи своєчасного оперативного лікування за умов «німого» перебігу атеросклеротичних змін, характерних для ЦД.

\section{Список використаної літератури}

1. Караченцев ЮІ, Дунаєва ІП. Цукровий діабет 2 типу та ішемічна хвороба серця. Навчальний посібник для лікарів-ендокринологів, сімейних лікарів, лікарів-інтернів, лікарів-слухачів закладів (факультетів) післядипломної освіти. - Харків: Водний спектр Джі-Емі-Пі; 2017. 124 с. (Karachentsev YI, Dunaeva IP. Type 2 diabetes mellitus and coronary heart disease. Textbook for endocrinologists, family doctors, interns, doctors-students of institutions (faculties) of postgraduate education. - Harkiv: Water spectrum of GMP; 2017. 124 p.).

2. Евсеева ЯВ, Курильская ТЕ, Рунович АА. Ультразвуковое исследование вазодилатационных реакций эндотелия у больных сахарным диабетом 2 типа, ассоциированным с ишемической болезнью сердца и артериальной гипертонией. Кардиоваскулярная терапия и профилактика. 2005;4(6), ч. II: 2006;4(4):8791. (Evseeva YaV, Kurilskaya TE, Runovich AA. Ultrasound examination of vasodilation reactions of the endothelium in patients with type 2 diabetes mellitus associated with ischemic heart disease and arterial hypertension. Cardiovascular Therapy and Prevention. 2005;4(6), part II: 2006;4(4):87-91).

3. Всесвітня організація охорони здоров’я [Інтернет]. Дата публікації від 08.06.2020. Режим доступу: https://www.who. int/ru/news-room/fact-sheets/detail/diabetes (World Health Organization. [Internet]. Date of publication from 08.06.2020. Available from: https://www.who.int/ru/news-room/fact-sheets/ detail/diabetes).

4. Зюзина ЖВ. Роль сахарного диабета в развитии коронарного атеросклероза у лиц трудоспособного возраста: клинико-генетические аспекты (обзор литературы). Кремлевская медицина. Клинический весник. 2019;1:75-86. (Zyuzina ZhV. The role of diabetes mellitus in the development of coronary atherosclerosis in people of working age: clinical and genetic aspects (literature review). Kremlin medicine. Clinical spring. 2019;1:75-86).

5. Петухов ВА. Дисбиоз, эндотоксиновая агрессия, нарушение функций печени и дисфункция эндотелия в хирургии. Современный взгляд на проблему. Трудный пациент. 2006;4(4):10-16. (Petukhov VA. Dysbiosis, endotoxin aggression, liver dysfunction and endothelial dysfunction in surgery. A modern view of the problem. Difficult patient. 2006;4(4):10-16).

6. Бондарь ИА, Демин АА, Шабельникова ОЮ, Онянова ВА. Изменения толщины комплекса интима-медиа общей сонной артерии у больных сахарным диабетом II типа в сочетании с артериальной гипертензией. Сахарный диабет. 2014;(1):416. (Bondar' IA, Demin AA, Shabel'nikova OYu, Onyanova VA Assessment of carotid intimamedia thickness in patients with type II diabetes mellitus and arterial hypertension. Diabetes Mellitus. 2014;(1):41-6).

7. Pignoli P, Tremoli E, Poli A, Oreste P, Paoletti R. Intimal plus medial thickness of the arterial wall: a direct measurement with ultrasound imaging. Circulation. 1986;74(6):1399-1406.

8. Иванникова ЕВ, Калашников ВЮ, Смирнова ОМ. Влияние факторов роста фибробластов и конечных продуктов гликирования на толщину комплекса интима-медиа у больных с ишемической болезнью сердца и сахарным диабетом 2 типа. Сахарный диабет. 2014;(2):47-55 (Ivannikova EV, Kalashnikov VYu, Smirnova OM. Influence of fibroblast growth factors and end products of glycation on the thickness of the intima-media complex in patients with ischemic heart disease and type 2 diabetes mellitus. Diabetes Mellitus. 2014;(2):47-55)

9. Lorenz MW, Price JF, Robertson C, et al. Carotid intima-media thickness progression and risk of vascular events in people with diabetes: results from the PROG-IMT collaboration. Diabetes Care. 2015;38(10):1921-9.
10. Akazawa S, Tojikubo M, Nakano Y, et al. Usefulness of carotid plaque (sum and maximum of plaque thickness) in combination with intima-media thickness for the detection of coronary artery disease in asymptomatic patients with diabetes. J Diabetes Investig. 2016;7(3):396-403.

11. Katakami N, Matsuoka TA, Shimomura I. Clinical utility of carotid ultrasonography: Application for the management of patients with diabetes. J Diabetes Investig. 2019;10(4):883-98.

12. Katakami N, Mita T, Gosho M, et al. Clinical Utility of Carotid Ultrasonography in the Prediction of Cardiovascular Events in Patients with Diabetes: A Combined Analysis of Data Obtained in Five Longitudinal Studies. J Atheroscler Thromb. 2018;25(10):1053-66

13. Алан ПЛ, Даббінс ПА, Позняк МА, МакДікен ВН. Клінічна допплерівська ультрасонографія. 2-ге вид. Пер. 3 англ. Павлюк В, Шимечко О. Львів: Медицина світу; 2007. 374 с. (Allan PL, Dubbins PA, Pozniak MA, McDicken WN. Clinical Doppler ultrasonography. 2nd ed. Pavluk V, Simechko O, trans. Lviv: Medicine of the World; 2007. 374 p.).

14. Цвибель ВДж, Пеллерито ДС. Ультразвуковое исследование сосудов. Борисенко ВВ, Кремнева ЕИ, Киселева МИ, и др., переводчики. Москва: Издательский дом Видар-М; 2008. 646 с. (Zwibel WJ, Pellerito JS. Ultrasound examination of blood vessels. Borisenko VV, Kremneva EI, Kiseleva MI, et al., translators. Moskva: Vidar-M Publishing house; 2008. 646 p.).

15. Егорова МС, Кондратюк ВЕ, Кузнецова СМ, Комиссарова ОС. Атеросклероз и структурно-функциональное состояние сосудов каротидного и вертебробазиллярного бассейнов. Сімейна медицина. 2019;(4):83-9 (Ehorova M, Kondratuk V, Kuznetsova S, Komissarova O. Atherosclerosis and the structural and functional state of the vessels of the carotid and vertebrobasilar basins.Famaly medicine. 2019;(4):83-9).

16. Hoke M, Schillinger M, Minar E, et al. Carotid ultrasound investigation as a prognostic tool for patients with diabetes mellitus. Cardiovasc Diabetol. 2019;18:90.

17. Панченко ЕП, Беленков ЮН. Характеристика и исходы атеротромбоза у амбулаторных больных в Российской Федерации (по материалам международного регистра REACH). Кардиология. 2008;(2):1724. (Panchenko EP, Belenkov YuN. Characteristics and outcomes of atherothrombosis in outpatients in the Russian Federation (based on the international registry REACH). Cardiology. 2008;(2):17-24).

18. Василькова ОН, Мохорт ТВ, Науменко ЕП, и др. Клиническая оценка факторов риска каротидного атеросклероза у пациентов с сахарным диабетом 2-го типа, осложненным хронической болезнью почек. Нефрология. 2016;(1):62-8 (Vasilkova ON, Mohort TV, Naumenko EP, et al. Clinical assessment of risk factors for carotid atherosclerosis in patients with type 2 diabetes mellitus complicated by chronic kidney disease. Nephrology. 2016;(1):62-8).

19. Gao X, Song J, Watase H, et al. Differences in Carotid Plaques Between Symptomatic Patients With and Without Diabetes Mellitus. Arterioscler Thromb Vasc Biol. 2019;39(6):1234-9.

20. García-López ZY, Vargas-Barrón J. Evaluation of the global longitudinal strain and segmental strain of the right ventricle with two-dimensional speckle-tracking echocardiography with elevation of the legs. Arch Cardiol Mex. 2019;89(1):15-9.

21. Тимина ИЕ, Бурцева ЕА. Ультразвуковое исследование брахиоцефальных артерий. Серия «Лучшие практики лучевой и инструментальной диагностики». Вып. 28. 2-е изд. перераб. и доп. Москва: ООО «Принт»; 2019. 40 с. (Timina IE, Burtseva EA. Ultrasound examination of the brachiocephalic arteries. Series «Best practices of radiation and instrumental diagnostics». Issue 28. 2nd rev. add. ed. Moskva: LLC «Print»; 2019. 40 p.).

22. Куліков ВП. Основы ультразвукового исследования сосудов. Москва: Издательский дом Видар-М; 2015. 392 с. (Kulikov VP. Fundamentals of vascular ultrasound examination. Moskva: Vidar-M Publishing house; 2015. 392 p.).

23. Носенко НМ, Щеглов ДВ, Друк ГВ. Питання стандартизації протоколу ультразвукового дослідження судин шиї: огляд сучасних рекомендацій. Ендоваскулярна нейрорентгенохірургія. 2019;(2):73-85 (Nosenko NM, Shchehlov DV, Druk HV. Issues of standardization of the protocol of ultrasound examination of the vessels of the neck: a review of current recommendations. Endovascular neuroradiosurgery. 2019;(2):73-85).

(Надійшла до редакиії 23.11.2020 р.) 
Лекції

\section{Скрининг сонных артерий у больных с сахарным диабетом: методология и клиническая значимость}

\section{М.С. Черская, Х.Н. Кухарчук, О.А. Гаевая}

ГУ «Институт эндокринологии и обмена веществ им. В.П. Комиссаренко НАМН Украины»

Резюме. Сахарный диабет (СД) является независимым фактором риска фатальных и не фатальных сердечно-сосудистых заболеваний (СС3). На сегодняшний день, по данным Всемирной организации здравохранения, в мире СД болеют около 422 млн человек, что составляет 8,8\% населения. Установлено, что СС3 являются основной причиной смерти у больных сахарным диабетом. Тревожит то, что при СД очень часто наблюдается поражение сосудов. Причиной этому является патогенетически обосновано быстрое прогрессирование атеросклеротического поражения сосудов, которое может бессимптомно прогрессировать десятки лет до момента наступления неблагоприятных сердечно-сосудистых событий. Следует учитывать, что на фоне СД изменения сосудистой стенки в виде атеросклеротического поражения имеют более прогрессирующее течение, чем у пациентов без СД. Все это указывает на необходимость ранней диагностики изменений сосудистой стенки у больных с СД. Результаты ряда клинических исследований позволяют расценивать ультразвуковую диагностику (УзД) сосудов, а именно сонных артерий, как скрининговый метод «первой линии» атеросклеротического поражения особенно у больных с СД. Данный метод является не только неинвазивным, безопасным, безболезненным, быстрым и не дорогим, но и достоверным. УзД сосудов дает возможность на ранних этапах выявлять начальные и уже имеющиеся атеросклеротические изменения сосудистой стенки у бессимптомных больных, контролировать эффективность лечения, дальнейшее прогрессирование заболевания. В данной статье мы также представили результать собственного исследования, методологию определения маркеров атеросклероза - толщину комплекса интима-медиа и атеросклеротические бляшки с помощью УзД. Использование УзД сонных артерий, как метода выбора у больных с ЦД, позволит своевременно определять риск развития ССЗ и их осложнений у пациентов с СД.

Ключевые слова: сахарный диабет, сердечно-сосудистые заболевания, ультразвуковая диагностика сосудов шеи, толщина комплекса интима-медиа, атеросклеротическая бляшка.

\section{Screening of carotid arteries in patients with diabetes mellitus: methodology, and clinical importance}

\section{Chers'ka, Kh. Kukharchuk, O. Haiova}

SI «V.P. Komisarenko Institute of Endocrinology and Metabolism of the National Academy of Medical Sciences of Ukraine»

Abstract. Diabetes mellitus (DM) is an independent risk factor for fatal and non-fatal cardiovascular disease (CVD). Today, according to the World Health Organization data, about 422 million people in the worldwide suffer from diabetes, which is $8.8 \%$ of the world's population. It is established that CVD are the leading cause of death in patients with DM. It is also worrying that in diabetes, vascular damage is quite common. The reason for this is the pathogenetically justified rapid progression of atherosclerotic vascular lesions, which may progress asymptomatically for decades until the onset of adverse cardiovascular events. It should be born in mind that against the background of DM, changes in the vascular wall in the form of atherosclerotic lesions are more progressive course than in patients without DM. All this indicates the need for early diagnosis of changes in the vascular wall in patients with DM. This is confirmed by the results of a number of clinical studies in which it is recommended to consider ultrasound diagnosis of blood vessels, namely the carotid arteries, as a screening method of «first line» for atherosclerotic lesions, especially in patients with DM. This method is not only non-invasive, safe, painless, fast and inexpensive, but also reliable. Vascular ultrasound makes it possible in the early stages to detect initial and already existing atherosclerotic changes of the vascular wall in asymptomatic patients, to monitor the effectiveness of treatment and further progression of the disease. The article presents the methodology for determining and clinical significance of early markers of atherosclerosis - the thickness of the intimamedia complex and the presence of atherosclerotic plaques - using vascular ultrasound. Thus, the use of ultrasound diagnostics of the carotid arteries, as a method of choice in patients with DM, will make it possible to timely determine the risk of developing CVD and their complications.

Keywords: diabetes mellitus, cardiovascular diseases, ultrasound diagnostics of neck vessels, thickness of intima-media complex, atherosclerotic plaque.

Для цитування: Черська MC, Кухарчук ХМ, Гайова ОА. Скринінг сонних артерій у хворих на цукровий діабет: методологія і клінічна значимість. Ендокринологія. 2020;25(4):355-362. DOI: 10.31793/1680-1466.2020.25-4.355

Відомості про авторів: Марія Сергіївна Черська, канд. мед. наук, ORCID: 0000-0002-3689-2683; Христина Миколаївна Кухарчук, лікар, ORCID: 0000-0002-2495-2693; Ольга Анатоліївна Гайова, ліkap, ORCID: 0000-0003-1309-1899.

Особистий внесок: М.С. Черська - концепція та дизайн дослідження, збір, аналіз та інтерпретація даних, редагування і остаточне затвердження статті; Х.М. Кухарчук - збір даних, аналіз та інтерпретація даних, редагування статті; О.А. Гайова - збір даних, аналіз та інтерпретація даних, написання і редагування статті.

Фінансування: Стаття підготовлена в рамках бюджетного фінансування Національною академією медичних наук України.

Декларація з етики: Автори задекларували відсутність конфлікту інтересів і фінансових зобов'язань. 